\title{
THE GREEK TRANSLATORS OF THE PROPHETICAL BOOKS.
}

IN preceding numbers of the JoURNAL ${ }^{1}$ I have given reasons for believing that the task of translating the books of Jeremiah and Ezekiel into Greek was in each case divided between two translators. The striking fact that the break in each book comes at nearly the halfway point suggested that this division of labour was the result of the collaboration of two contemporary translators. It must, however, be admitted that another explanation is not impossible, namely that the earliest Greek version of both books was an incomplete one, which was afterwards supplemented by another worker. The question as to which of these views is correct could only be decided by the discovery of some sure linguistical criteria for distinguishing a Greek translation made in the second century B.c. from a translation belonging to one of the succeeding centuries.

May we equate any of the four hands which we have traced in these two books? The second hand in Jeremiah (Jer. $\beta$ ) and the second hand in Ezekiel (Ez. $\beta$ ) each present certain distinctive features of their own, and can certainly not be equated, nor (apart from the reappearance of Jer. $\beta$ in the book of Baruch) is there any trace of either of these two hands elsewhere in the prophetical books of the Greek Bible. But the earlier portion of the Greek Jeremiah (Jer. $a$ ) and the remaining portion of Ezekiel (Ez. $a$ and $\gamma$ ) together with the version of the Minor Prophets show a considerable affinity in their vocabulary, which renders it not improbable that they were all produced at about the same time, if not actually by one and the same hand.

In dealing with large groups of books such as this, it is difficult to prove identity of translators. All that can be attempted here is to show that these books or portions of books have very many details in common, and that as translations they are sharply distinguished from the Greek Isaiah.

33. omne benedictione celeste Gell ; omnem? benedictionem $\mathrm{S}$. 34. de multitudinem Gell. 35. Anastasia cum (' et' added by another hand) Ang. 36 . prestes $R$. 37. Before Lord's Prayer, rubric: Orat, $R$. 38. Before 'Libera nos,' rubric: Sequtur oratio, Ang; Item sequitur oratio, $S$, Gell.

The following, though not unica, must also be mentioned here: 39. 'ut' omitted before 'placatus accipias,' $R, 2296$. 40. dispone (for 'disponas') $R$ and Sacr. Godelgaud (see Ménard, Notae, p. 15, Migne $P . L$ lxxviii 276). 41. Simile modo Bo, Gell. 42. novi aeterni testamenti, $R, S, G e l l$ (and Bergamo MS of Ambros.). 43. effunditur Bo, Gell. 44. praeclarae majestatis Bo, Gell, 45. benedices et praestas, Bo, Gell. 46. opem misericordiae, Bo, Gell.

J. T. S. vol. iv, pp. 245 ff., 398 ff. 
With regard to the Minor Prophets, the discovery of the two hands in Jeremiah and the two in Ezekiel had led me to expect to find a similar division of labour in this group also. In this, however, I have been disappointed. The Greek versions of the Minor Prophets are linked together by the recurrence in the opening and closing books and throughout the collection of certain rare words and usages. I have failed to detect any clear indication of the work of more than one hand. The following are some instances of words and uses which occur in more than one of the Minor Prophets but not elsewhere in the LXX. 'A

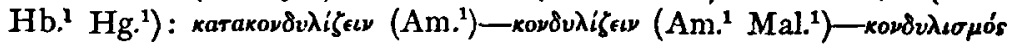
(Zeph. $\left.{ }^{1}\right)$ : $\pi$ oór 'a first-ripe fig' (Ho. ix Io, Na. iii I 2): xáos = N' (Mi.' Zech.').

A noteworthy connecting link between the versions of Jeremiah and the Minor Prophets is found in their rendering of the Divine name 'Lord of hosts' (יהוה צבאות), a phrase in the rendering of which a well-marked distinction in the books of the LXX may be observed. It is rendered (I) Kíptos $\sigma a \beta a \omega \dot{\theta} \theta$ in I Kings (five times), and Isaiah

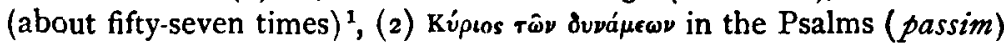
and in some few passages elsewhere, (3) Kúpıos Паитокрárop in Jeremiah (in both parts, about fifteen times in all : in numerous instances the phrase 'Lord of hosts' occurs in the Hebrew where it is omitted in the Greek), the Minor Prophets (Hos. Am. Mic. Na. Hab. Zeph. Hag. Zech. $\mathrm{Mal}$.), in some few passages in 2 and 3 Kings and 1 Chron., and in the Greek books. The Hebrew phrase, it should be noted, is absent from Ezekiel. In this case, it will be seen, Jeremiah $\alpha$ and $\beta$ are not distinguished from each other.

I have already in Table $I$ in my first paper ${ }^{2}$ noted several instances where the first portion of Jeremiah agrees in its renderings with Ezekiel (the agreement is usually confined to Ezekiel $a$ and $\gamma$ ) and the Minor Prophets. Thus, in the second of the instances there quoted, we find

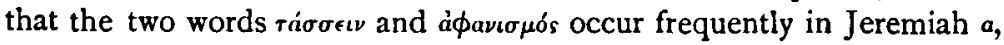
Ezekiel $(a$ and $\gamma$ ) and the Minor Prophets as the renderings of two not uncommon Hebrew words, but are unrepresented in Isaiah. This mutual agreement of Jer. $a$, Ezek. $a$ and $\gamma$, Min. Prophets, and the exclusion of Isaiah from this group may be attested by numerous examples. As I have said, I think that it points to the translation of the group being a single undertaking, that is to say, the translations were made at one time, and, if not by a single translator, at any rate by a small group of collaborateurs. It is probable, as will be shown later,

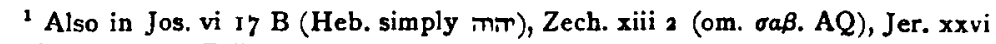
I0 $\mathrm{AQ}$ (om. $\sigma \alpha \beta . \mathrm{BN}$ ).

Vol. iv, pp. 247 ff. 
that the version of Isaiah had been already made, and that the rest of the prophetical group or the bulk of it was then translated en bloc. It is quite possible that a closer examination than I have yet made will reveal divergences of rendering within the group, but the general agreement is, I think, unmistakable.

The following table contains a selection of some of the most striking examples where Jer. $a$, Ezek. $a$ and $\gamma$, and Min. Prophets or two of these three books (the Minor Prophets in the Greek must, as was said, be treated as a single book) stand alone ${ }^{1}$, or nearly alone in their rendering of a Hebrew word or phrase, or in their employment of the same Greek word ${ }^{2}$.

1. פלט

\section{Table IV.}

(a) Jer. $a$ Ezek. $a$ and $\gamma$ and Minor Prophets.

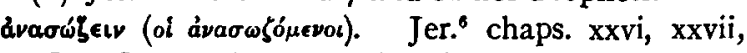
xxviii [li 14] (Lam. $\left.{ }^{1}\right):$ Ezek. $^{8}\left(a^{7} \beta^{1}\right):$ Min. ${ }^{7}$ (Am. Jl. Ob. Zech.).

The Greek word occurs elsewhere in Hist. books ${ }^{3}$, Maccab. ${ }^{3}$ The Heb. is rendered elsewhere by $\sigma \dot{\omega}\left\langle\epsilon \omega \nu, \delta_{i} a-\right.$ $\sigma \dot{\omega}\langle\epsilon \iota \nu$ and (Psalms) $\dot{\rho} \dot{v} \epsilon \sigma \theta a c$.

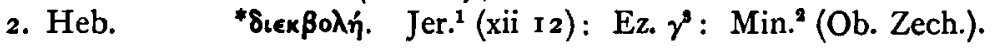
various The verb occurs in Joshua.

קבץ

4. usu. ד or

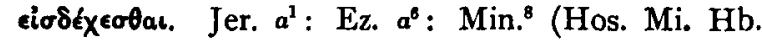
Zeph. Zech.). Only else in Greek books.

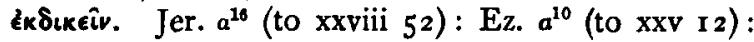
Min. ${ }^{21}$ The verb is not common in other translated books. Is. has it once only $(=2$ ר)

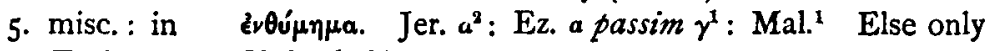
Ezek. גלולים

6. ירלים I Ch. ${ }^{1}, \Psi^{1}$, Sir.

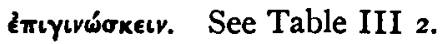

1 These instances are indicated by an asterisk.

2 It will be seen that Lamentations agrees with this group in some renderings. Both the recent Bible dictionaries (s.v. 'Lamentations') assert that this book cannot have been translated by the 'translator of Jeremıa.' The original authority for this statement is Noldeke (Die altest. Literatur, I 868, p. I44). The only reason which he gives is that 'die [Uebersetzung] der Klagelieder ist recht wortlich, die des Jeremia frei und sehr nachlässig,' and this dictum is unsupported by any examples. I was at first inclined to think that Lamentations might belong to the group containing Jeremiah $a$. So far as vocabulary goes, they have a certain amount in common :

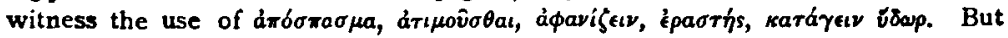
some differences, e. g. the regular rendering of $a$ in Lamentations by kai $\gamma \epsilon$, and

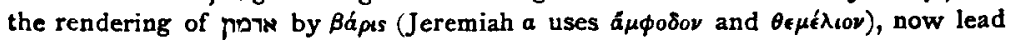
me to think that the Greek of Lamentations is the work of another and a later hand. 
7. usu. ipaorins. Jer. $a^{8}\left(\right.$ Lam. $\left.^{1}\right)$ Ez. $a^{8}:$ Hos. $^{5}$ Also twice in pi. Wisdom.

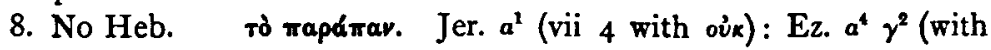
$\left.\mu \dot{\eta}^{\prime}\right)$ : Zeph. ${ }^{1}$ (iii 6). Also in 3 K. xi 10.

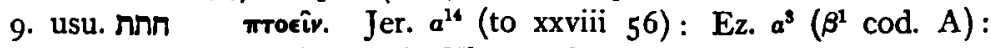
Min. ${ }^{\circ}$ (Am. Ob. Hb.). Also in Is. ${ }^{1}$, and in a few other isolated passages. Cf. ámrónтos, Jer. xxvi 28, xxvii 2.

נואון נסו

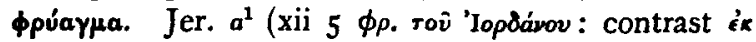

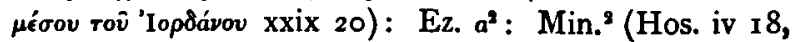
Zech. xi 3 rò $\phi \rho$. roũ 'Iopdduvv).

Other renderings ï $\beta \rho$ s Jer. xiii 9, xxxi 29, Ez. $\beta^{4}$,

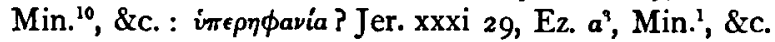

(b) Jer. $a$ and Ezekiel.

II.

I2. רכב

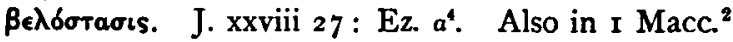

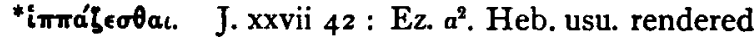
imıßaivetv, as in Min. Proph., and (with åppara) twice in Jer. a. Cf. imraria below.

I3.

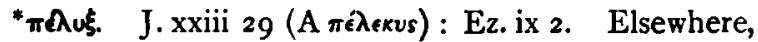

14. שים including J. xxii $7, \pi \in \lambda \in$ evus.

фapétpa. J. xxviii II : Ez. xxvii II. See Streane, R.V. 'shields' Double text, p. 296. The Greek renders other Heb. R.V.mg. 'suits words elsewhere.

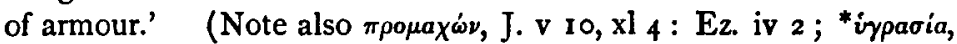
J. xxxi 18 : Ez. vii 17 , xxi 7.)

(c) Jer. $a$ and Minor Prophets.

15.

ערב . ער

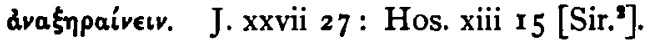

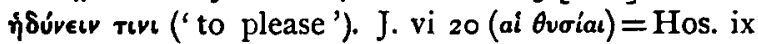
$4(a i \theta v \sigma$.$) . Elsewhere the verb occurs seven times with$ the accusative or in the passive.

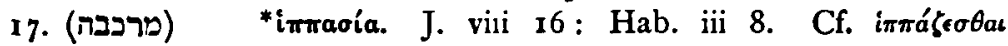
above.

18.

Tò'Iraßúpıor'. J. xxvi 18 : Hos. v1. So in Josephus

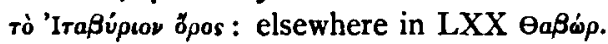

19.

20. נבור

2I. משא

Kúpıos חavtoxpátwp. See above.

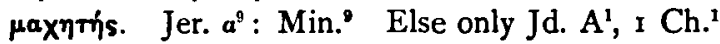

Other renderings are yiras Ez. $\beta$ \&c., ouvarós passim,

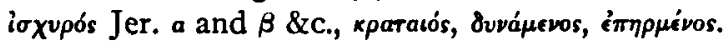

$\lambda \hat{\eta} \mu \mu a$. Jer. $a^{7}$ (Lam. ${ }^{1}$ ): Min. ${ }^{7}$ (Na. Hb. Hg. Zech. Mal.). Also in $2 \mathrm{~K}^{1}, 4 \mathrm{~K}^{2}, \mathrm{Job}^{1}$. Not in Isaiah, which

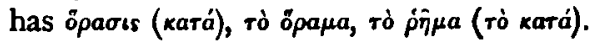

1 The mountain in Palestine is called 'Araßúpion in Polybius v 706. This form of the name indicates a connexion between the Hellenized form of Tabor and mount Atabyris or Atabyrium in Rhodes. 
22. ג'a troop'

23.

24.

25. תאנה

26.

27.

28. נפח

29.

30.

3 I.

32.

סרר סרנ

34 .

35 .
סרב

$=\lambda_{\text {norís }}$ in J. xviii 22 and Hos. vii I only. The Heb. is rendered in a variety of ways elsewhere: yed8oú $\rho$,

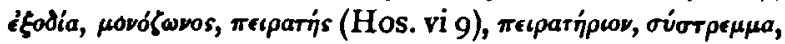
\&c.

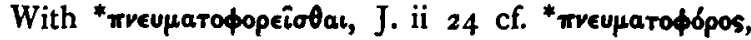
Hos. ix 7, Zeph. iii 4 .

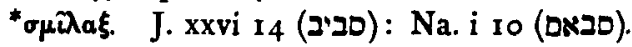

*oukóv. J.v 17 : Am. iv 1o. Elsewhere, including J. viii 13 , Min. ${ }^{10}$, бukiे.

(d) Ezekiel $a$ and $\gamma$ and Minor Prophets.

*amokwфoûv. Ez. iii 26, xxiv 27: Mic. vii 16. Else-

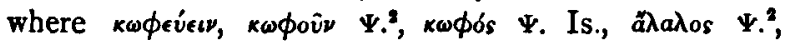

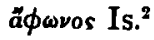

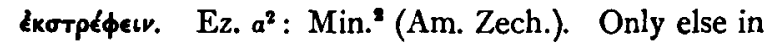
Deut. ${ }^{1}$

exфưâv. Ez. $a^{2}$ : Min. ${ }^{2}$ (Hg. Mal.). Else only twice in Greek books.

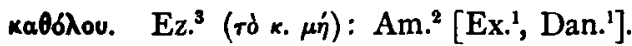

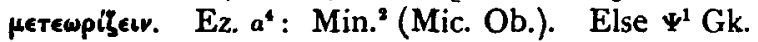
books'.

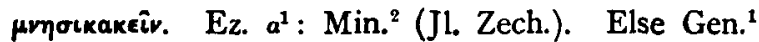
Prov. ${ }^{1}$

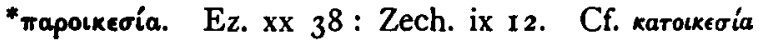
Ez. vi 14 ( $\left.\operatorname{Lam}^{1}{ }^{1}\right)$.

* Tapocotpâr. Ez. ii 6: Hos. iv 16.

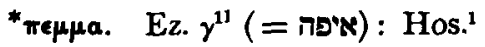

оuнфúpeotal. Ez. $a^{1}$ : Hos. ${ }^{1}$ [Sir. $\left.{ }^{1}\right]$.

This positive evidence may be supplemented by a certain amount of negative evidence, namely the absence from this group of books of such common words as kata (one doubtful instance in Ez. $a$ and one in Jonah),

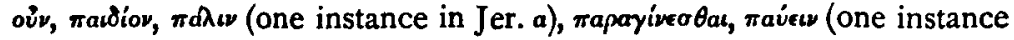

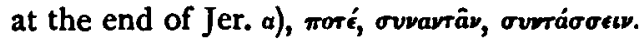

In some instances Jeremiah a diverges from the group, and Ezekiel and the Minor Prophets seem to be somewhat more closely related to each other than they are to Jeremiah. Thus, the following, which are used in common by Ez. $a$ and $\gamma$ and the Minor Prophets, are absent

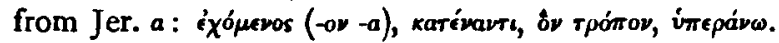

The instances given above in Table IV may not in themselves be sufficient to establish identity of translators. Some of them might be due to imitation. I think, however, that the general agreement in vocabulary existing in these prophetical books affords strong cumulative 
evidence that we have here another group ${ }^{1}$ answering to that earlier group of the five books of the Greek Pentateuch for which the earliest tradition and all intrinsic evidence indicate a common origin.

As to the position of the Greek Isaiah, its rendering of 'Lord of hosts' is sufficient by itself to distinguish it from the group which we have been considering. The translator is, moreover, less competent on the whole than the translator or translators of the Jeremiah group?, though he tries to hide his ignorance by paraphrase or abbreviation, occasionally giving the general sense of a passage, whlle omitting to render the difficult words. Such deliberate deviation from the original is quite foreign to the translators of the other prophetical books, who honestly, although often with little success, try to find an equivalent for every word in the Hebrew. On the other hand, the Isaiah translator, while careless about producing a literal rendering, employs a Greek which much more nearly approaches the classical style than the Greek of the more painstaking translators of the other prophetical books. This may be illustrated by his use of connecting particles. Kai, $\delta \dot{\epsilon}$, yáp are freely inserted, where there is no corresponding Hebrew word; we may

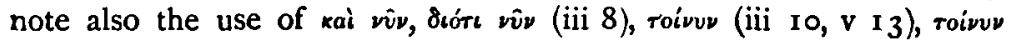

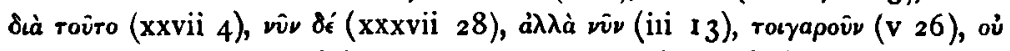

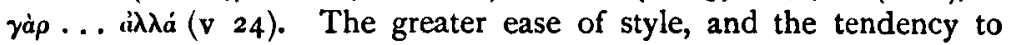
give a free rather than a verbatim rendering, are, I think, marks of a comparatively early date. Another characteristic of the Isaiah translation, which perhaps also points to an early date, is the agreement which it shows in some of its renderings with the book of Exodus. An ephah

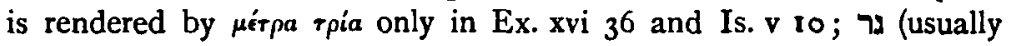

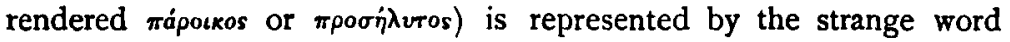

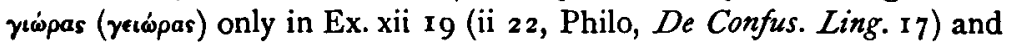
Is. xiv I; the anthropomorphism by which Jehovah is called 'a man of war'

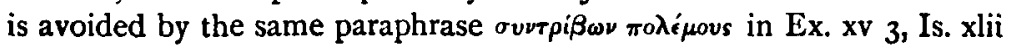

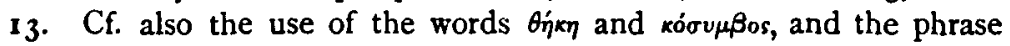
cis rò̀ aî̄va xpóvov (Ex. xiv 13, Is. seven times). With Genesis the

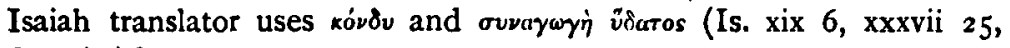
Gen. i 9) ${ }^{\text {s. }}$

Further results may, I believe, be obtained in the grouping of the

1 Dr. Ryle says, on the other hand, 'The only considerable portion of the translation done at the same time and by the same hands is the Pentateuch' (Canon of the $O T$, pp. $1_{4} 6 \mathrm{f}$.).

'Swete, Introd. to O. T., p. 316.

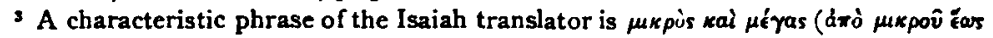
$\mu \in \gamma^{\prime} \lambda$ ov). He seems to have recourse to this when in doubt as to the meaning of the Hebrew. It occurs as the equivalent of five different Hebrew phrases (ix 14

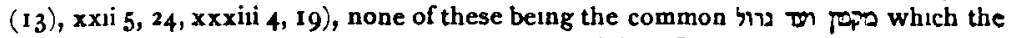
Greek phrase ordinarily renders in other parts of the LXX. 
books of the LXX by a careful study of their style and vocabulary. As an instance of this I should like, in concluding this note, to mention that, just as the Greek Isaiah stands apart from the other prophetical books, so I Kingdoms seems to stand apart from the other three Books of Kingdoms and the Book of Judges. Although, owing to a large admixture of Hexaplaric readings ${ }^{1}$, it is difficult to arrive at the earliest text in these books, and there is no clear evidence of so close a connexion as appears to exist between the later prophetical books, yet there are certain features common to, and practically confined to Jd., 2, 3 and 4 Kingdoms, in which, as in other respects, they are distinguished from I Kingdoms. Thus, the peculiar

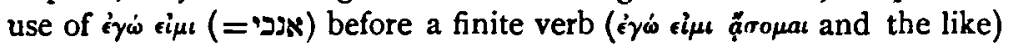
is practically confined to Jd. (B text five times, A text once), Ruth, $2 \mathrm{~K}$. (seven times: also vii $29 \sigma \dot{v}$ ci $\dot{\lambda} \lambda \dot{\lambda} \lambda \eta \sigma a s$ ), $3 \mathrm{~K}$. (once), $4 \mathrm{~K}$. (three times) ${ }^{2}$. Kepariv for 'trumpet' (שפ) is confined to Jd. (B and A texts ten times), $2 \mathrm{~K}$. (four times) ${ }^{3}, 3 \mathrm{~K}$. (three times), $4 \mathrm{~K}$. (once), $2 \mathrm{Ch}$. A text (once), and Nehemiah (twice); whereas $\sigma a ́ \lambda \pi r \gamma \xi$ is used in I K. and elsewhere. The same combination is seen in the use of the

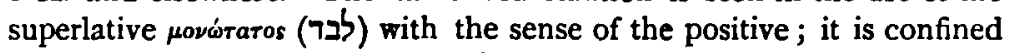
to Jd. (once), $2 \mathrm{~K}$. (thrice), $3 \mathrm{~K}$. (five times), $4 \mathrm{~K}$. (twice), and 2 Chron. vi $30 \mathrm{~A}$. I Kingdoms uses rovos, which is found along with poviraros in 2,3 and $4 \mathrm{~K}$. Note also the use of the following in $\mathrm{I}$ K.: Báravos (= 'guilt-offering'), the transliteration yeodov' (= גרור : 2, 3, $4 \mathrm{~K}$.

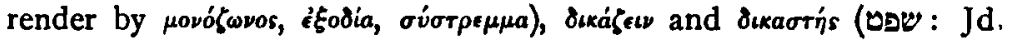

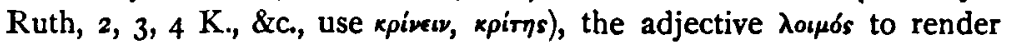
'(sons of) Belial' ( $\pi a p a$ áopos in Dt., Jd., 2, 3 K., \&c.). Many of the renderings in Jd., 2, 3, $4 \mathrm{~K}$. mentioned above find attestation in some part of the Hexapla. I should be inclined to say that the original Greek of these books, when all due allowance has been made for the subsequent intrusion of Hexaplaric readings, was akin in many respects to that of the later Greek versions (Aquila, \&c.), and that the versions of these historical books were made at a comparatively late date. I Kingdoms represents the first attempt to translate 'the earlier prophets' (ביאים ר), as the Greek Isaiah exhibits the first attempted rendering of ' the later prophets' (נביאים אחרונים). It is curious to note that it is only in these two books that the Divine title יהוה צבאיתות is consistently represented by Kípros $\sigma a \beta a \dot{\omega} \theta$.

1 A striking instance is seen in 3 Kingdoms, in which book most of the large lacunae in the B text of the LXX are supplied in cod. A from Aquila (see viil I, ix 15 ff. \&cc.).

Also Job xxxiil $3^{1}$, Ez xxxvi $3^{6 \mathrm{~A}}$.

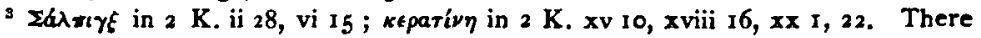
is other evidence for a distinction between the earlier and later portions of this book. 
It may be worth while briefly to state the conclusions reached :-

r. Isaiah was the first of the prophetical books to be rendered into Greek.

2. The first half of Jeremiah, the greater part of Ezekiel, and the whole of the Minor Prophets were afterwards translated en bloc, possibly by a single hand, possibly by a small group of collaborateurs.

3. The remaining portions of Jeremiah and Ezekiel exhibit a style quite distinct from that which is found in the last-named group. These portions may have been made at the same time as the last group (this part of the work, with a view to expediting the translation of these two long books, being entrusted to persons not conversant with the methods of the translator or translators of the rest of the group), or they may be the work of a still later date, the earliest versions of these books having been only fragmentary.

4. In the case of Ezekiel, and possibly in other books, the rendering given of the lessons read on the great festivals, such as Pentecost, in the synagogues at Alexandria, formed the basis on which a complete translation was afterwards engrafted.

5. I Kingdoms was like the Greek Isaiah, a first attempt at rendering one of the main divisions of the Hebrew Bible, and exhibits a different style from that of the later versions of 2,3 and 4 Kingdoms.

H. St. J. Thackeray.

\section{ON SOME CHRISTIAN GRAVESTONES FROM OLD DONGOLA.}

A FEw months ago Mr. Carl Armbruster, of King's College, Cambridge, and now of the Nubian Civil Service, sent to Cambridge three fragmentary gravestones with Greek inscriptions which had been long used as building material near Old Dongola. They are of interest as coming from so far up the Nile, for Old Dongola is about halfway between the great dam of Așwân and Khartum itself. There is also a further feature of interest arising from the fact that one of the stones is dated 8I 2 A.D, a curiously late date for a Greek inscription from the heart of Nubia. The other two stones, however, look earlier, and may be assigned to the seventh and eighth centuries. But in any case they seem to be later than the Mohammedan conquest of Egypt. 